\title{
クロマトグラフィー分離を基盤とした新しいプロテオーム解析による臨床薬学研究
}

\author{
大山 要
}

\section{Clinical Pharmaceutical Research Based on New Proteome Analysis Based on Chromatographic Separation}

\author{
Kaname Ohyama \\ Graduate School of Biomedical Sciences, Nagasaki University; 1-7-1 Sakamoto, Nagasaki 852-8588, Japan.
}

(Received July 31, 2018)

\begin{abstract}
Comprehensive identification of antigens in immune complexes (IC-antigens) is beneficial to provide insights into pathophysiology and could form the basis for novel diagnostic and treatment strategies for many immune-related diseases. Immune complexome analysis is a method for comprehensively identifying and profiling IC-antigens in biological fluids (such as serum and cerebrospinal fluid). We applied this strategy to the analysis of circulating ICs in autoimmune diseases (rheumatoid arthritis, Sjögren's syndrome, systemic scleroderma, and systemic lupus erythematosus), infectious diseases, and cancers. Fluorogenic derivatization-liquid chromatography-tandem mass spectrometry (FD-LC-MS/ MS) consists of fluorogenic derivatization of proteins, followed by HPLC of the derivatized proteins, isolation of the proteins differentially expressed in a certain group, enzymatic digestion of the isolated proteins followed by LC-tandem MS using a database-searching algorithm for protein identification. We have applied this method to understand the cardioprotective effect of pre-administration of docetaxel in adriamycin/docetaxel combination anti-cancer therapy, and the cellular processes that are affected by non-steroidal anti-inflammatory drugs (NSAIDs) in mouse stomach tissue during ulcer formation.
\end{abstract}

Key words_-immune complexome analysis; immune complex; toxicoproteomics; autoimmune disease; cancer; fluorogenic derivatization-liquid chromatography-tandem mass spectrometry

\section{1. 生体内特異的認識機構を利用する生体情報解} 析法の開発（抗原-抗体複合体を中心に）

免疫系は異物を“自己”と区別して認識・除去し, 外敵から生体を守る生体防御機構である.しかし, この免疫系の破綻は重大な疾患を招く。例えば，自 己免疫疾患では免疫系がなんらかの理由で “自己” に対しても反応し局所や全身性の炎症を引き起こ す。また，がん細胞は異物として認識されるはずで あるが，免疫系による除去が不十分なため体内で増 殖することができると考えられている，よって，自 己免疫疾患やがんの形成過程で免疫系が何を抗原と して認識しているのか，という点が疾患毎にわかれ ば，この抗原に基づく研究は診断や病態解明に留ま らず新しい治療法の開発へと一気に展開できる。一

長崎大学生命医科学域（薬学系）（８552-8588 長崎市 坂本 1-7-1)

e-mail: k-ohyama@nagasaki-u.ac.jp

本総説は, 平成 29 年度日本薬学会九州支部学術奨励賞

の受賞を記念して記述したものである.
方, 自己免疫疾患ではサイトカインを標的とした分 子標的治療, がんでは免疫チェックポイント阻害薬 が目覚しい治療成果をあげている。しかし，いずれ の治療も全身の免疫を調節するため, 免疫抑制（感 染症の再燃）又は免疫賦活（重症筋無力症や 1 型糖 尿病）による副作用が懸念されている. そのため, 疾患特異的な抗原を見つけられれば，免疫調節を “全体”から“点”へと移行させることが可能にな るかもしれない.

生体内の免疫反応点, すなわち抗原の同定は, $\mathrm{T}$ 細胞又は B 細胞が産生する抗体が認識する抗原群 から探索するというもので，そのほとんどが $\mathrm{T}$ 細 胞側からのアプローチである. ${ }^{1-3)}$ 筆者は, 抗体と 抗原の結合親和性が $\mathrm{T}$ 細胞受容体の 1000 倍以上で ある，末梢血中にも豊富に存在する，in vivo での 抗原認識がそのまま反映される，という観点から B 細胞側, 特に免疫複合体の直接解析が有効だと考え た。そこで筆者は，生体内で安定的に存在し抗原認 識そのものと言える免疫複合体を生体内から回収し 


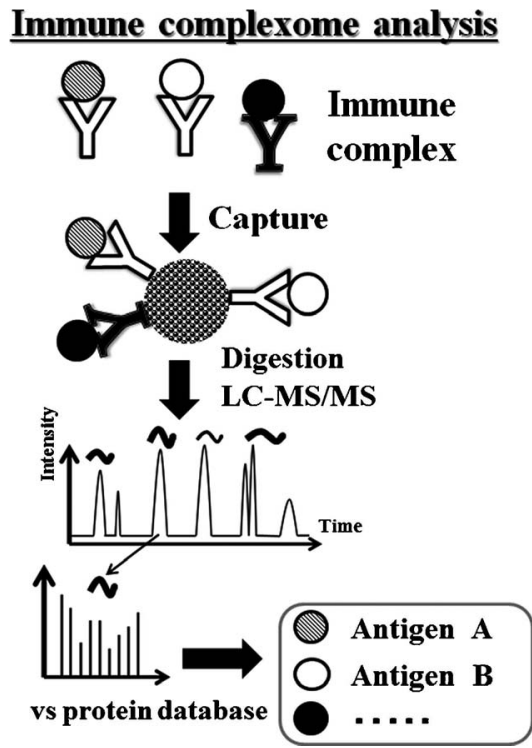

Fig. 1. Immune Complexome Analysis to Profile Antigens Included in Circulating Immune Complexes

て，そこに含まれる抗原タンパク質をナノ高速液体 クロマトグラフィーータンデム質量分析法（nanoLC-MS/MS）で一斉に同定する「イムノコンプレ キソーム解析法」（Fig. 1）を開発し，臨床検体の 解析に応用してきた. ${ }^{4,5}$

筆者はまずこの解析法で関節リウマチ患者 60 名 と変形性関節症や他の自己免疫疾患患者の血清を解 析して，関節リウマチ患者のみで特異的自己抗原 （Thrombospondin-1）が高頻度（80\%以上）に検出 されること,4) そしてこの Thrombospondin-1 が血 液検查陰性の早期関節リウマチ患者の半分以上で検 出されることを発見した。 ${ }^{6}$ Thrombospondin-1の

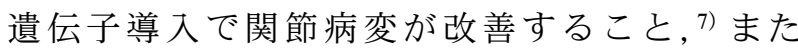
Thrombospondin-1 が免疫複合体を形成したことで その機能が低下し血管新生が促進されること，を考 慮すると発症との関連性が十分に考えられる，そし て，筆者は患者の滑膜組織で Thrombospondin-1 が 強発現し，Thrombospondin-1 が滑膜線維芽細胞で 血管内皮細胞増殖因子や interleukin-6 の産生を誘 導することを見い出している. ${ }^{8)}$ さらに筆者は，関 節リウマチ以外の 8 種類の自己免疫疾患（全身性工 リテマトーデス，シェーグレン症候群，皮膚筋炎， 強皮症など）の解析を行った. 9 ,10) この解析では, シェーグレン症候群で Spectrin が検出され，既報 と一致する結果が得られた。 ${ }^{11)} ま た ，$ 血清以外の試 料の解析にも取り組んでおり, 脳脊髄液を用いた中
枢神経ループス，多発性硬化症，視神経脊髄炎など の中枢神経性自己免疫疾患のイムノコンプレキソー ム解析で特異的な抗原タンパク質を発見してい る. ${ }^{12,13)}$

一方，がん細胞を標的とした免疫賦活化での治療 研究で, 14,15) 腫瘍反応性の CD8 陽性又は CD4 陽性 $\mathrm{T}$ 細胞を特定する方法が複数報告されている. ${ }^{16,17)}$ しかし，これらの多くは患者腫瘍組織の遺伝子解析 であり，遺伝子変異数が多いメラノーマでは有効だ が，遺伝子変異以外の抗原部位を特定できない。一 方，イムノコンプレキソーム解析法では，様々な要 因で変異したタンパク質ががん細胞破壊後に漏出 し，これを認識し形成された免疫複合体から抗原と して検出される.よって，イムノコンプレキソーム 解析法で検出された変異タンパク質の細胞表面での 局在が確認できれば，がん免疫療法での標的となり 得る。そこで筆者は，肺がん患者 28 名，大腸がん 患者 20 名, 悪性リンパ腫患者 9 名及び健常人 11 名 を解析し，その結果を自己免疫疾患患者とも比較し た結果，肺がんでは 10 個，大腸がんでは 2 個の特 異的自己抗原が見つかつた。 大腸がんで検出された 2 個の抗原の検出頻度はいずれも $18 \%$ だつたのに対 し, 肺がんで検出された 10 個の抗原のうち 3 個が 患者の $60 \%$ 以上で検出された。肺がんで最も高い 検出頻度（80\%）を示した Gelsolin は，追加解析 した，腎がん・尿路がん・乳がんや間質性肺炎など の肺良性疾患でも検出されず，肺がんへの高い特異 性が示された. ${ }^{18)}$

筆者の一連の成果を受け，免疫複合体の抗原側を 固定化抗体でとらえる免疫複合体マイクロアレイや 免疫複合体の選択的な捕集法が報告されるなど，免 疫複合体解析によるバイオマーカー探索が活発に研 究され始めている. ${ }^{19-22)}$ これに対し筆者は，免疫複 合体中の抗原タンパク質を診断用としてだけでな く, “病原”としてとらえ，関節リウマチや中枢神 経ループスで特定した特異的免疫複合体が病態形成 の端緒となる可能性があることまで調べており，他 グループに先駆けて創薬研究への応用も進めてい る。具体的には，抗原性の根幹であるエピトープを 特定し，それを標的に免疫複合体の形成を阻害する 薬物の作製を目指す研究を展開している，また，循 環血中の免疫複合体解析よりも，実際の病変部位を そのまま解析した方が直接的な病態解明につながる 
と考え, 組織に沈着している免疫複合体を回収し, その抗原を特定する “組織沈着した免疫複合体のイ ムノコンプレキソーム解析法” の確立にも取り組ん でいる.

一方, イムノコンプレキソーム解析法は免疫が関 連するあらゆる疾患の解析に応用できる. よって,

筆者は感染症, 肝臓移植, 不妊症カップルの解析も 進めている. 特に感染症では, デング出血熱や重篤 な心肥大と巨大結腸症を起こすシャーガス病に注目 し解析を行っている. 患者体内の免疫複合体に含ま れるウイルスあるいは原虫由来の抗原タンパク質を 一斉に同定し, 感染抵抗者と重症感染者を差異解析 することで, 感染抵抗者のみあるいは感染抵抗者で 多量に認められる抗原タンパク質の有無を調べてい る，既にシャーガス病では，原虫の細胞表面に存在 するプロテアーゼが感染抵抗者で高頻度に検出され る抗原として見つかり, ${ }^{23)}$ そのエピトープ解析やエ ピトープを標的とするワクチン開発に向けた共同研 究を計画している.

以上のように, イムノコンプレキソーム解析法 が, 病態解析における更なる応用だけでなく, 解析 で見つかつた特異的抗原は治療研究の標的にもなる 可能性があり，発展性と将来性に富んだ研究である と考えている.

\section{2. タンパク質の精密クロマトグラフィー分離に} よる薬物毒性機序の研究

Fluorogenic derivatization-liquid chromatographytandem mass spectrometry (FD-LC-MS/ MS) 法は, タンパク質の発蛍光誘導体化と長時間の精密なクロ マトグラフィー分離による差異解析を行うため, 夕 ンパク変動を超高感度（femto モルレベル）かつ網 羅的に捉えることができる。. ${ }^{24,25)}$ 筆者はこの FDLC-MS/MS 法で薬物毒性の機序をトキシコプロテ オミクス的観点から考える研究に取り組んできた. 筆者はまず，血液疾患や乳がんの治療に用いるアン トラサイクリン系抗がん剤アドリアマイシンが，そ の繰り返し投与で心毒性を生じる機序を FD-LCMS/MS 法で調べた。 具体的には，心毒性を誘発す る抗がん剤（アドリアマイシン）と別の抗がん剂 （ドセタキセル）を同時あるいは間欠投与した後の マウス心臓組織に発現する全タンパク質の差異解析 を行った。その結果, 両群間で解糖系や TCA 回路 などのエネルギー産生系に関与する複数の酵素の発
現量に有意な変化が認められた，特に，解糖系酵素 である GAPDH の変動は大きく，間欠投与群では その発現量が 7 倍多く，心毒性が顕著に抑制される ことが判明した。 つまり，アドリアマイシンの投与 で心臓での GAPDH 量が著しく減少し ATP 産生が 抑制されることで心臟機能が弱まる可能性が示され た. ${ }^{26)}$

アスピリンなどの非ステロイド性抗炎症薬 (non-steroidal anti-inflammatory drugs; NSAIDs) は，安全性の高い薬剤として広く使用されている が，一方で NSAIDs 潰瘍による胃腸障害が臨床上 大きな問題となっている。 NSAIDs 潰瘍は, NSAIDs がシクロオキシゲナーゼ（cyclooxygenase; COX) - 2 だけでなく，胃粘膜保護に係わる COX-1 も非選択的に抑制することが原因と考えられてき た。しかし，COX-2 選択的 NSAIDs でも依然 NSAIDs 潰瘍の発生が認められていることから, COX 経路以外の潰瘍発現メカニズムの存在が予想 されている。 そこで筆者は，FD-LC-MS/MS 法で NSAIDs（ジクロフェナク）投与後に潰瘍形成が確 認されたマウス胃組織のプロテオーム解析を行つ た. ${ }^{27)}$ NSAIDs 投与群と対照群とした生食投与群と の比較で統計的に有意な差がある 10 個のタンパク 質が同定された。いずれのタンパク質も NSAIDs 投与群で発現が上昇しており，なかでも小胞体スト レス応答 (GRP78), カスパーゼ (HSP27),

MAPK 経路（gastrin）などアポトーシスに関連す るタンパク質の変動が大きかった。 胃粘膜表面のア ポトーシス障害は胃潰瘍と密接に係わるとの報告が あることから, 解析結果は妥当なものと考えられる.

GRP78 や HSP27 は anti-apoptosis であり, gastrin は pro-apoptosis であるため, それぞれの機能促進 あるいは抑制による NSAIDs 潰瘍に対する予防効 果の可能性が示唆された. ${ }^{27)}$

さらに最近は, 脳マイクロダイアリシスにおける サンプリングが脳に及ぼす組織障害を FD-LC-MS/ MS で解析する研究に取り組んでいる。脳マイクロ ダイアリシス法は, 脳に挿入した微小透析プローブ を介し神経伝達物質や薬物が含まれる細胞外液や髄 液を人工脊髄液を灌流することで連続的に回収する 方法として汎用されているが, 組織侵襲の大きいサ ンプリング法である．筆者はプローブ挿入後の灌流 でどのようなダメージが発生するか調べ，そのダ 
メージを最小限にすることが解析上重要と考えて, プローブ挿入後の灌流の有無でのラット脳組織の夕 ンパク質がどのように変動するのかを網羅的に解析 している.この解析結果は, これまで漠然と想像さ れていたマイクロダイアリシスによる組織侵襲を夕 ンパク質の網羅的解析で明らかにした初めての研究 になると期待している.

このように FD-LC-MS/MS 法は，薬物毒性機序 に限らず，物理的侵襲を含め，あらゆる外部刺激に 対する生体反応をタンパク質変動の観点から, 高感 度かつバイアスなしに調べられる，非常に有用な ツールである.よって，今後も更なる応用研究を展 開できると考えている.

謝辞本研究を遂行するにあたり，ご助言を賜 りました長崎大学生命医科学域（薬学系）黒田直敬 教授，中嶋幹郎教授，岸川直哉准教授に謹んで感謝 申し上げます，本研究は，塩川明菜さん，馬場雅子 さん, 吉見春香さん, 相原希美さんの精力的な仕事 の成果であります。深く感謝申し上げます。本研究 に際し，有益なご協力を頂きました，武蔵野大学薬 学研究所 今井一洋先生, 一番ヶ瀬智子先生に深謝 いたします。また本研究は，以下の共同研究者から の検体提供と解析結果へのご助言を得て遂行されま した，深く感謝申し上げます。川上 純教授，玉井 慎美准教授，中村英樹講師，一瀬邦弘講師，岩本直 樹助教，鈴木貴久博士（以上，長崎大学病院リウマ チ・膠原病内科), 中村洋一先生（栃木県立がんセ ンター), 江口 晋教授, 日高匡章助教, 藤田文彦 先生（長崎大学病院第二外科），宮田康好准教授 (長崎大学病院泌尿器科), 今泉芳孝講師（長崎大学 病院血液内科), 中嶋秀樹助教（長崎大学病院脳神 経内科), 北島道夫准教授, 村上直子先生（以上, 長崎大学病院産婦人科), 平山謙二教授, Nguyen Tien Huy 准教授, 水上周作助教（以上，長崎大学 熱帯医学研究所免疫遺伝学分野), 山本元久助教, 高橋裕樹准教授（以上，札幌医科大学医学部消化 器・免疫・リウマチ内科学講座), 伊藤公成教授, 増山律子准教授（以上，長崎大学歯学部), 藤 秀 人教授, 友成真理博士 (富山大学薬学部)。本研究 は，科学研究費補助金（基盤研究 $\mathrm{B}$, 挑戦的萌芽研 究, 若手研究 B), 武田科学振興財団, 東京生化学 研究会, 永尾武難病研究基金, 加藤難病研究助成基
金，薬学研究奨励財団，島原科学振興会からの研究 助成並びに, 長崎大学大学院医歯薬学総合研究科融 合型研究推進事業, 長崎大学高度化推進経費, 長崎 大学熱帯医学共同研究拠点一般共同研究, 長崎大学 重点研究課題の各事業からの研究助成を受けて遂行 されました。ここに感謝申し上げます。

利益相反＼cjkstart開示すべき利益相反はない.

\section{REFERENCES}

1) Ito Y., Hashimoto M., Hirota K., Ohkura N., Morikawa H., Nishikawa H., Tanaka A., Furu M., Ito H., Fujii T., Nomura T., Yamazaki S., Morita A., Vignali D. A. A., Kappler J. W., Matsuda S., Mimori T., Sakaguchi N., Sakaguchi S., Science, 346, 363-368 (2014).

2) Robbins P. F., Lu Y. C., El-Gamil M., Li Y. F., Gross C., Gartner J., Lin J. C., Teer J. K., Cliften P., Tycksen E., Samuels Y., Rosenberg S. A., Nat. Med., 19, 747-752 (2013).

3) Linnemann C., van Buuren M. M., Bies L., Verdegaal E. M. E., Schotte R., Calis J. J. A., Behjati S., Velds A., Hilkmann H., Atmioui D., Visser M., Stratton M. R., Haanen J. B. A. G., Spits H., van der Burg S. H., Schumacher T. N. M., Nat. Med., 21, 81-85 (2015) .

4) Ohyama K., Ueki U., Kawakami A., Kishikawa N., Tamai M., Osaki M., Kamihira S., Nakashima K., Kuroda N., Clin. Chem., 57, 905-909 (2011).

5) Baba M., Ohyama K., Kishikawa N., Kuroda N., Anal. Biochem., 443, 181-186 (2013).

6) Ohyama K., Kawakami A., Tamai M., Baba M., Kishikawa N., Kuroda N., Ann. Rheum. Dis., 71, 1916-1917 (2012).

7) Jou I. M., Shiau A. L., Chen S. Y., Wang C. R., Shieh D. B., Tsai C. S., Wu C. L., Arthritis Rheum., 52, 339-344 (2005).

8) Suzuki T., Iwamoto N., Yamasaki S., Nishino A., Nakashima Y., Horai Y., Kawashiri S., Ichinose K., Arima K., Tamai M., Nakamura H., Origuchi T., Miyamoto C., Osaki M., Ohyama K., Kuroda N., Kawakami A., J. Rheumatol., 42, 943-947 (2015).

9) Ohyama K., Baba M., Tamai M., Aibara N., 
Ichinose K., Kishikawa N., Kawakami A., Kuroda N., Clin. Biochem., 48, 181-185 (2015).

10) Ohyama K., Baba M., Yamamoto M., Tamai M., Ichinose K., Kishikawa N., Takahashi H., Kawakami A., Kuroda N., Mod. Rheumatol., 26, 248-250 (2016).

11) Haneji N., Nakamura T., Takio K., Yanagi K., Higashiyama H., Saito I., Noji S., Sugino H., Hayashi Y., Science, 276, 604-607 (1997) .

12) Ichinose K., Ohyama K., Furukawa K., Higuchi O., Mukaino A., Satoh K., Nakane S., Shimizu T., Umeda M., Fukui S., Nishino A., Nakajima H., Koga T., Kawashiri S., Iwamoto N., Tamai M., Nakamura H., Origuchi T., Yoshida M., Kuroda N., Kawakami A., Clin. Immunol., 193, 123-130 (2018).

13) Aibara N., Ichinose K., Baba M., Nakajima H., Satoh K., Atarashi R., Kishikawa N., Nishida N., Kawakami A., Kuroda N., Ohyama K., Clin. Chim. Acta, 484, 26-31 (2018).

14) Hodi F. S., O'Day S. J., McDermott D. F., Weber R. W., Sosman J. A., Haanen J. B., Gonzalez R., Robert C., Schadendorf D., Hassel J. C., Akerley W., van den Eertwegh A. J., Lutzky J., Lorigan P., Vaubel J. M., Linette G. P., Hogg D., Ottensmeier C. H., Lebbé C., Peschel C., Quirt I., Clark J. I., Wolchok J. D., Weber J. S., Tian J., Yellin M. J., Nichol G. M., Hoos A., Urba W. J., N. Engl. J. Med., 363, 711-723 (2010) .

15) Hinrichs C. S., Rosenberg S. A., Immunol. Rev., 257, 56-71 (2014).

16) Schumacher T. N., Schreiber R. D., Science, 348, 69-74 (2015).
17) Overwijk W. W., Nat. Med., 21, 12-14 (2015).

18) Ohyama K., Yoshimi H., Aibara N., Nakamura Y., Miyata Y., Sakai H., Fujita F., Imaizumi Y., Chauhan A. K., Kishikawa N., Kuroda N., Int. J. Cancer, 140, 370-380 (2017).

19) Rho J. H., Lampe P. D., J. Proteome Res., 12, 2311-2320 (2013).

20) Bhat S., Mary S., Banarjee R., Giri A. P., Kulkarni M. J., Proteomics Clin. Appl., 8, 19-34 (2014).

21) Kamhieh-Milz J., Sterzer V., Celik H., Khorramshahi O., Fadl Hassan Moftah R., Salama A., J. Proteomics, 157, 59-70 (2017).

22) Cheng Y., Zhao X., Chen Y., Li Y., Jia R., Xhu L., Huang C., Sun X., Deng H., Li Z., PLoS ONE, 13, e0199047 (2018).

23) Ohyama K., Huy N. T., Yoshimi H., Kishikawa N., Nishizawa J. E., Iihoshi N., Roca Y., Avilas C., Gianellar A., Lora J., Velarde F. U. G., Kuroda N., Hirayama K., Parasite Immunol., 38, 609-617 (2016).

24) Masuda M., Toriumi C., Santa T., Imai K., Anal. Chem., 76, 728-735 (2004).

25) Ichibangase T., Moriya K., Koike K., Imai K., J. Proteome Res., 6, 2841-2849 (2007) .

26) Ohyama K., Tomonari M., Ichibangase T., To H., Kishikawa N., Nakashima K., Imai K., Kuroda N., Biochem. Pharmacol., 80, 540547 (2010).

27) Ohyama K., Shiokawa A., Ito K., Masuyama R., Ichibangase T., Kishikawa N., Imai K., Kuroda N., Biochem. Biophys. Res. Commun., 420, 210-215 (2012). 